\title{
QUO VADIS MARKETING PERBANKAN SYARIAH DI ERA MILENIAL INDUSTRI 4.0
}

\author{
Edy Junaedi \\ Dosen STAI Asy-Syukriyyah Tangerang \\ edy.junaedi@asy-syukriyyah.ac.id
}

\begin{abstract}
Abstrak
Penelitian ini bertujuan untuk melakukan investigasi pengaruh aset industri bank syariah, sumber daya insani industri bank syariah dan non performing financing industri bank syariah terhadap market share bank syariah Indonesia. Sampel yang digunakan adalah populasi industri bank syariah dari Otoritas Jasa Keuangan (OJK) Republik Indonesia. Menggunakan analisis regresi $F$ Test dan T Test dengan software SPSS versi 22. Hasil Uji F menunjukan bahwa aset bank syariah, sumber daya insani dan non performing financing secara simultan berpengaruh terhadap market share bank syariah. Hasil uji T menunjukan bahwa aset bank syariah secara parsial berpengaruh signifikan terhadap market share bank syariah, variabel sumber daya insani bank syariah dan non perfotming financing secara parsial tidak berpengaruh terhadap market share bank syariah. Disrupsi di pelayanan keuangan perbankan mengubah strategi pemasaran syariah, disrupsi di kantor cabang, pembayaran berbasis kartu, ATM, internet banking (berbasis web), uang tunai, customer service, tradisional call center, sms banking, E money dan produk, bisnis juga criptocurrency, E commerce, credit, waqf, asuransi kesehatan milenial, aplikasi berbasis online, perilaku bayar nanti, aware terhadap riba, pembayaran digital, investasi online, perencanaan keuangan, kredit digital, top up game dan angsuran $0 \%$. Untuk mampu hidup di abad milenial dibutuhkan strategi yang mengakomodasi apa yang diharapkan oleh kaum milenial, dengan Leap Strategies agar bisa meningkatkan market share bank syariah lebih dari 5 persen.
\end{abstract}

Kata Kunci : Indutsri Bank Syariah, asset, Human Capital, Pemasaran.

\section{Abstract}

This study aims to investigate the influence of Sharia Banking Industry's assets, the human capital of the Sharia Banking Industry and Non Performing Financing of Sharia Banking Industry to the Marketshare of Shariah banks in Indonesia. Sampling using sample or the entire population of Islamic banking from Sharia Banking Statistics Financial Services Authority, Republic of Indonesia. Analysis tool using regression analysis using $F$ test and $t$ test with SPSS ver.22.00. The results $F$ Test showed that the Shariah Banking Industry's Asset, the human capital of the Sharia Banking Industry and Non Performing Financing of Sharia Banking Industry simultaneously affect the marketshare in Islamic banks. The results T Test showed that Sharia Banking industry's 
assets has partially significant effect on the marketshare of Islamic Banks, Variables such as human capital of Sharia Banking Industry and Non performing Financing have no partially effect on the marketshare of Sharia banks. Disruption in banking finansial services changes sharia marketing startegic, disruption in branch office, card based payment, ATM, internet banking (web based), cash, customer service, traditional call center, sms banking, E money and product, business also cryptocurreency, E commerce credit, Waqf, millennial friendly health insurance, online based application, pay later behavior, riba awareness, digital payment, online investment, financial planning, digital lending, game top up dan installment 0\%. To be able live in millenial century needed business strategy that acomodate millenial people hope, Leap Strategies. In order to make sharia banking marketshare more than 5 percent.

Key Words: Sharia Banking Industry, asset, Human Capital, Marketshare.

\section{A. PENDAHULUAN}

Tahun ini menandai berakhirnya era 2010-an dan kita memasuki dekade 2020-an.

Sebuah era dimana tiga perubahan besar telah betul-betul menemukan critical massnya.Tiga perubahan tersebut adalah disrupsi digital (digital disruption), disrupsi milenial (millennial disruption), dan disrupsi leisure (leisure disruption). ketiganya disebut dengan istilah Three Market Megashifts.

Disrupsi digital ditandai perubahan dari atoms ke bits yang menciptakan modelmodel bisnis baru berbasis digital dengan marginal cost yang mendekati nol. Disrupsi milenial ditandai pergeseran pasar dari Gen-X ke milenial dimana terjadi perubahan perilaku yang ekstrim. Sementara disrupsi leisure ditandai bergesernya pola konsumsi dari berbasis barang (goods-based consumption) ke pengalaman (experience-based consumption) Apa dampak dari tiga Megashift tersebut? Dampaknya luar biasa. Industri seperti 'dirusak' dan bergeser dari 'old normal' untuk kemudian memasuki masa transisi 'disrupted normal' dan akhirnya menuju keseimbangan baru menjadi 'new normal'.

Di tengah perubahan tersebut, di satu sisi ada produk, bisnis, dan industri lama berguguran. Sementara di sisi lain banyak produk, bisnis, dan industri baru begitu pesat bermunculan. Ada yang bangkrut, ada yang muncul baru. Di industri layanan keuangan 
misalnya, kantor cabang, anjungan tunai mandiri (ATM), kartu kredit, dan layanan tunai semakin ditinggalkan konsumen. Sementara digital payment, digital lending, credit scoring berbasis artificial intelligence (AI) justru mulai marak digunakan. Di industri ritel, hypermarket, departement store, trade center semakin banyak berguguran. Sementara minimarket, mal berbasis kuliner, on-demand shopping/services, gerai artisan, sneakers store atau on-the-go store justru menjamur.

Di industri otomotif mobil sedan, motor bebek, penggunaan mobil pribadi semakin turun. Sebaliknya kendaraan jenis sport utility vehicle (SUV), mobil listrik, ridesharing hingga ride hailing mulai meningkat penggunaannya.

Fokus pusat pertumbuhan pada human capital (Karena itu memasuki dekade 2020-an ini kita berada di persimpangan jalan gugur-tumbuhnya industri lama dan baru sebagai dampak datangnya disrupsi. Industri demi industri segera memasuki 'radar disrupsi’ tanpa bisa mengelak. Karena itu pilihannya cuma satu: Lompat ! Leap!

Karena itu pula pergantian dekade ini menjadi momentum penting bagi para pemimpin bisnis untuk melompat (strategic leap) dari industri lama yang obsolet ke industri baru yang prospektif. Dalam kaitan itu Leap Strategy diawali dengan Unlearn, yaitu menganggap diri kita 'tak tahu semuanya'. Survive dari disrupsi bukanlah semata masalah teknologi digital atau inovasi model bisnis. Yang terpenting justru adalah masalah mindset, yaitu mindset yang menganggap bahwa kita telah 'tahu semuanya'. Ketika kita sudah merasa tahu semuanya maka semakin sulit pula kita menanggalkannya. Itu pula sebabnya disruptor di industri otomotif bukanlah Toyota yang 'tahu semuanya' mengenai otomotif tetapi oleh Tesla dan Google. Disruptor perhotelan bukan Hilton tetapi Airbnb yang 'tak tahu semuanya'. Disruptor layanan taksi bukanlah Blue Bird tapi Uber.

\section{B. PEMBAHASAN}

Mindset 'tahu semuanya' telah membutakan mata, hati, dan pikiran kita mengenai hal baru yang tidak kita ketahui. Di tengah disrupsi, mindset yang diperlukan bukanlah 'tahu semuanya' tetapi justru sebaliknya 'tak tahu semuanya'. Kita tak cukup sebatas 


\section{Jurnal Asy-Syukriyyah}

Learning tetapi juga Unlearning, yaitu mengosongkan hal-hal usang yang selama berpuluh tahun kita ketahui dan kita yakini kebenarannya. Unlearning akan mengosongkan isi pikiran kita sebersih mungkin, sebersih kanvas kosong.

Unlearn adalah titik mula Anda melakukan lompatan strategis menuju new normal. Untuk sukses melompat kita harus mengubah paradigma berpikir lama ke baru. Paradigma baru ini adalah Digital Way of Thinking. Dalam mengelola sumber daya (key resources) misalnya, kita harus mengubah paradigma dari ownership ke access. Logika lama mengatakan bahwa untuk memenangkan persaingan maka perusahaan harus menguasai dan memiliki aset dan sumber daya. Bisnis zaman now justru menggunakan prinsip asset-light dimana akses lebih penting dari kepemilikan aset. Model bisnis GoJek atau Airbnb menggunakan prinsip ini. Begitu pula dalam memosisikan konsumen, paradigmanya bergeser dari customer menjadi prosumer. Wikipedia tidak menulis sendiri jutaan konten bermutu yang disajikan ke kita. Wikipedia menyerahkan penulisan itu kepada kita semua. Artinya, kita tidak hanya menjadi konsumen Wikipedia tetapi sekaligus juga produsen. Istilah kerennya: Prosumer.

Contoh lain adalah perubahan paradigma berpikir dari product ke platform. Android tidak menawarkan produk tetapi platform yang memungkinkan pihak lain, yaitu para pengembang aplikasi untuk berkreasi mengembangkan beragam varian produk yang memenuhi kebutuhan unik atau customized dari setiap pengguna smartphone. Industriindustri lama kini telah 'dirusak' oleh disrupsi, sehingga menghasilkan entitas industri baru yang berbeda sama sekali. Untuk sukses melompat, tidak bisa tidak, kita harus mengubah secara ekstrim paradigma berpikir.

Bagaimana dengan industry perbankan syariah Indonesia, yang masih berkutat dengan membesarkan market share selama sepuluh tahun terakhir ini dan terus dipusingkan oleh penyelesaian kredit macet, sementara dunia luar sudah berubah begitu cepatnya dengan seiring perkembangan teknologi informasi, seolah perbankan syariah menjadi tertinggal dalam kancah seluk beluk dunia marketing saat ini, semakin tidak dilirik. 


\section{Jurnal Asy-Syukriyyah}

\section{Gambar 1}

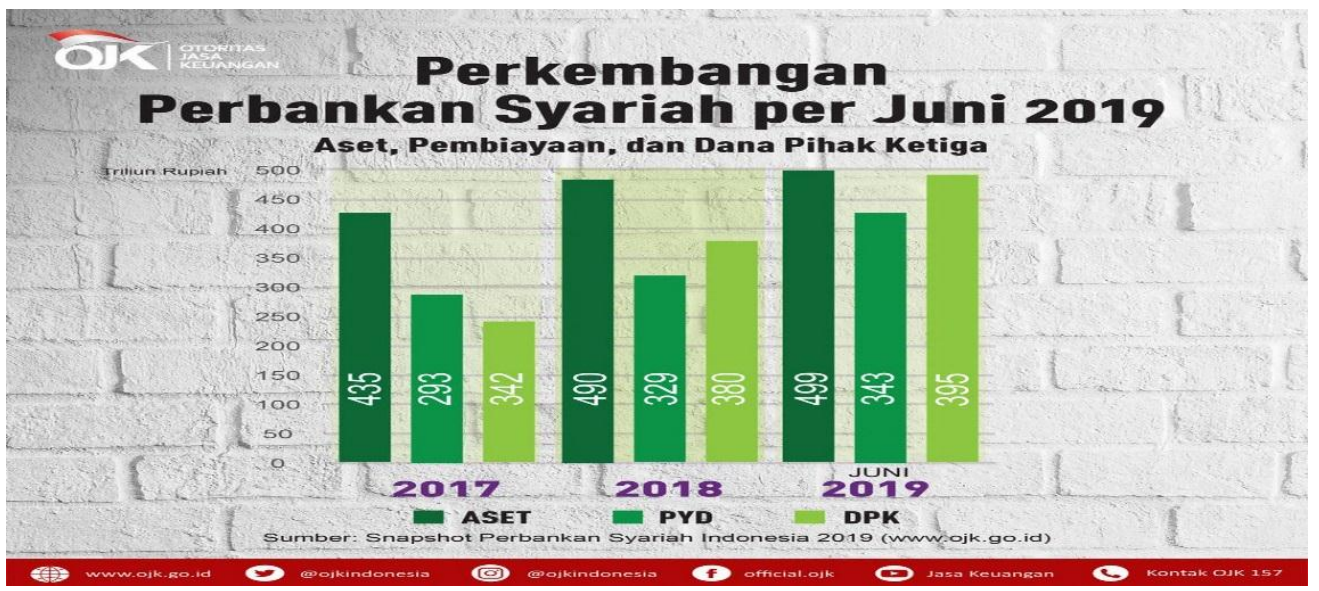

per Juni 2019 Otoritas Jasa Keuangan (OJK) mencatat pangsa pasar perbankan syariah memang masih bertengger di level 5,95\%. Porsi terbesar disumbang oleh BUS dengan nilai aset Rp322,95 triliun, yang bahkan tidak sampai setengah dari aset satu bank konvensional terbesar di Tanah Air.

Adapun market share perbankan syariah hingga kini cukup menjadi perhatian banyak pihak. Pasalnya, pertumbuhan market share perbankan syariah dalam lima tahun ini hanya bertumbuh dikisaran 1\%. Sisi lain memungkinkam Dual Banking Leverage Model (DBLM) akan efektif dalam mendongkrak pasar perbankan syariah khususnya dalam konteks efisiensi biaya. Artinya, UUS bisa mengoptimalkan infrastruktur pelayanan dan operasional yang dimiliki oleh induknya, dengan tetap menjaga dengan ketat unsur kepatuhan syariahnya.

Kita lebih kedalam lagi melihat perkembangan kinerja bank syariah, salah satunya kinerja Bank Umum Syariah PT Bank Muamalat Indonesia semakin memburuk. Laba bersih bank syariah pertama di Tanah Air ini anjlok pada semester I 2019. Di sisi lain rasio pembiayaan bermasalah Bank Muamalat kian menggunung. Mengutip laporan keuangan Bank Muamalat, Muamalat hanya mampu mengantongi laba bersih sebesar Rp 5,08 miliar sepanjang paruh pertama 2019. Capaian itu anjlok 95\% dibandingkan periode yang sama tahun 2018 yang sebesar Rp 103,7 miliar. Anjloknya perolehan laba bersih itu sejalan 


\section{Jurnal Asy-Syukriyyah}

dengan penurunan pendapatan penyaluran dana sebesar $24,7 \%$ dari 1,78 triliun menjadi $\mathrm{Rp}$ 1,34 triliun. Sedangkan bagi hasil untuk pemilik dana investasi cenderung stabil yakni Rp 1,13 triliun.

Pembiayaan Bank Muamalat juga melambat. Per Juni 2019, total pembiayaan bank ini hanya $\mathrm{Rp}$ 15,70 triliun yang terdiri dari Mudharabah Rp 461 miliar dan Musyarakah Rp 15,24 triliun. Padahal di periode yang sama tahun lalu, Bank Muamalat mencatat pembiayaan sebesar Rp 17,68 triliun yang terdiri dari Mudharabah Rp 548 miliar dan Musyarakah Rp 17,13 triliun. Artinya capaian pembiayaan bank ini melorot 10,7\% secara year on year (yoy) di paruh pertama tahun ini.

Total aset Bank Muamalat per Juni 2019 mencapai Rp 54,57 triliun atau turun dari Juni 2018 yang ketika itu mencapai Rp 55,18 triliun. Selain itu, kualitas aset Bank Muamalat juga semakin memburuk yang ditandai dengan meningkatnya rasio non performing financing (NPF). Per juni 2019, NPF gross Bank Muamalat membengkak menjadi $5,41 \%$ dari $1,65 \%$ pada Juni 2018. NPF net juga naik tajam dari $0,88 \%$ menjadi 4,53\% atau telah mendekati ambang batas normal sesuai ketentuan yakni 5\%.

Secara industry perbankan syariah tahun 2019 kredit macet bank syariah meningkat dari tahun sebelumnya, posisi Oktober 2019 kredit macet BUS sebesar 3.49 persen dan UUS sebesar 2.57 persen, dibanding posisi bulan Oktober 2018, BUS sebesar 3.95 persen turun sebesar 0.46 persen dan UUS sebesar 2.32 persen, naik 0.25 persen.

\section{Literature Review dan Hipothesis}

Teori-teori berkaitan dengan topic bahasan tentang materi pemasaran dan perkembangan teknologi serta teori tentang bank syariah adalah sebagai berikut : Perkembangan Ilmu Pemasaran

Ilmu pemasaran hari ini bergerak sangat cepat. Jika dulu ilmu kedokteran yang memiliki pergerakan update tercepat, nampaknya hari ini ilmu pemasaran yang memegang predikat tersebut. Begitu juga yang terjadi dalam empat tahun belakangan. Trennya terus bergeser. Seperti apa? jika dulu kiblat pemasaran tertuju ke dunia barat, saat ini bisa kita 


\section{Jurnal Asy-Syukriyyah}

klaim perkembangan terbarunya datang dari Asia, bahkan Indonesia, dunia Barat masih berperan besar karena memang ilmu pemasaran berawal dari sana ketika $\mathrm{P} \& \mathrm{G}$ melakukan brand management sekitar tahun 81 an. Saat ini product centric masih menjadi perhatian pemasar dunia. Jauh berbeda dengan beberapa tahun belakangan, yang sudah human centric atau bahkan paradox.

Beberapa tahun lalu masih berkutat brand 3.0. Brand menjadi sangat human centric yang telah bergeser dari product, service, dan customer centric. Di sini banyak lahir brand for good yang bukan hanya melahirkan profit tetapi juga planet dan people. Berikutnya kita melihat pendekatan marketing ke Brand 4.0 yakni brand yang bisa managing the paradox. Pada tahun 2017, brand telah diposisikan sebagai human. Brand telah mampu mentransformasikan diri dari sebagai identitas produk, bergeser menjadi customer personality, lalu menjadi human character.

Filosofi ini yang menjadi hal fundamental dalam membangun brand digital. Pasalnya, di era teknologi seperti sekarang ini, hanya manusia yang bisa memastikan teknologi akan berfungsi positif. Dan, ketika pemasaran bergeser dari tradisional ke digital melahirkan tiga paradox, yakni online vs offline, style vs substance, dan machine to machine vs human to human. Paradok ini yang harus di-manage oleh marketeer kala itu.

Beralih ke tahun 2018, kita semakin masuk ke era game of marketing. Untuk memenangkannya, positioning dan differensiasi harus diperkuat dari waktu ke waktu, tidak sekadar diperkuat, kedua juga harus didukung dengan servis level yang benar dan proses yang paling produktif. Brand pun harus semakin paham mengenai perubahan yang menyelimuti, persaingan yang Kian bertumbuh, konsumen yang kian bergeser, dan transformasi perusahaan. Branding dan marketing pun harus diintegrasikan dan melahirkan Omni Way. Lalu, bagaimana dengan tahun 2019? dua esensi, yakni omni brand dan momentum. Menurut Hermawan(4; 2017) Kita yang kini hidup di era VUCA (Volatility, Uncertainty, Complexity, Ambiguity) kita harus mampu mengambil momentum.

Satu hal yg paling berbahaya adalah ambiguity of company. kita tidak akan tahu harus ke mana atau bingung. Dari kondisi tersebut, akibatnya kita akan terjebak pada hal 


\section{Jurnal Asy-Syukriyyah}

taktikal saja tanpa berpikir strategis. Misalnya, ketika kompetitor menurunkan harga, maka kita ikutan. Lalu ketika pesaing meluncurkan produk baru dan kita juga meluncurkan produk baru untuk merespons pesaing, sayangnya, kita terjebak dan tidak tahu bagaimana harus menjadi leader.

Dibutuhkan DAMO (Discovery, Adventure, Momentum, Outlook). Satu hal yang paling penting di dalamnya adalah momentum. "Dalam hal ini,kita bisa mengerahkan Omni Way yang mereka sudah bangun in the right moment. Momentum is everything. Momentum pun bisa kita lahirkan sendiri atau memanfaatkan momentum yang ada. Perekonomian dunia, khususnya negara-negara berkembang seperti Indonesia, sedang bergerak menuju ekonomi digital. Perkembangan teknologi menjadi penggerak pertama perubahan tersebut. Organisasi dunia OECD (Organization for Economic Cooperation and Development) menyatakan, inovasi digital diklaim mampu membawa banyak negara lebih dekat pada kemakmuran yang berkesinambungan.

Gagasan tersebut tak bisa disangkal mengingat teknologi telah membuat proses produksi, pemasaran, distribusi, dan sebagainya menjadi lebih efisien dan efektif. Konektivitas yang dibangun pun memampukan banyak pelaku bisnis terhubung dengan akses-akses modal dan pasar yang baru. Peluang-peluang bisnis baru pun terbentang lebar dan ekonomi digital hadir sembari menjanjikan kemakmuran.

McKinsey pernah mendaftar inovasi yang dipercaya memberi dampak pada ekonomi secara signifikan. Sebut saja, internet, robotik, 3-D printing, dan sebagainya. Teknologi ini membantu mengembangkan sektor-sektor ekonomi, seperti sektor ritel dengan e-commerce, transportasi dengan kendaraan automatis, pendidikan dengan aneka kursus online, kesehatan, sampai interaksi sosial melalui media sosial.

Sementara itu, teknologi selain menyuguhkan aneka kemudahan, juga menyuguhkan aneka risiko. Selain memberi konektivitas, juga memberi "kekacauan." Selain membuat orang terpesona, juga membuat orang was-was. 


\section{Jurnal Asy-Syukriyyah}

\section{Pendekatan Pemasaran Baru}

Itulah kondisi di era transisi dari tradisional menuju era digital. Dalam konteks ini, dibutuhkan pendekatan pemasaran baru untuk membantu pemasar dalam mengatisipasi dan mengelola dampak teknologi yang disruptif tersebut. Dalam konteks inilah, Philip Kotler, Hermawan Kartajaya, dan Iwan Setiawan memperkenalkan konsep Marketing 4.0 dalam buku berjudul "Marketing 4.0, Moving from Traditional to Digital" Buku tersebut merupakan sekuel dari buku sebelumnya yang terbit enam tahun lalu, yakni "Marketing 3.0: From Products to Customers to the Human Spirit". Secara ringkas, buku tersebut memaparkan tiga pergeseran pemasaran utama, yakni dari product-driven marketing (Marketing 1.0) menuju customer-centricmarketing (Marketing 2.0) menuju human-centric marketing (Marketing 3.0).

Pada tahun ini, Marketing 4.0 diperkenalkan. Ini merupakan pendekatan pemasaran yang mengkombinasikan interaksi online dan interaksi offline antara perusahaan dengan pelanggan. Secara umum, Marketing 4.0 bisa dipahami seperti itu. Di era ekonomi digital, interaksi digital saja tidaklah cukup. Kenyataannya, justru di saat dunia online berkembang, sentuhan offline menjadi titik diferensiasi yang kuat. Selain mengkombinasikan online dan offline, Marketing 4.0 juga mengintegrasikan antara style dan substance. Artinya, merek tidak hanya mengedepankan branding bagus, tetapi juga konten yang relevan dengan pelanggan atau menyuguhkan konten yang bagus dengan kemasan yang up-to-date dan bagus.

Marketing 4.0 juga mengembangkan konektivitas machine-to-machine dan artificial intelligence dalam rangka mendongkrak produktivitas. Tetapi, itu harus diimbangi dengan pengembangkan konektivitas human-to-human yang justru akan memperkuat customer engagement. Intinya, pengembangan teknologi tidak berhenti pada teknologi itu sendiri, tapi bagaimana teknologi ini membantu merek dalam memanusiakan relasi dengan para pelanggannya. 


\section{Jurnal Asy-Syukriyyah}

\section{Pemasaran Tradisional Usang?}

Apakah dalam hal ini pemasaran tradisional menjadi usang? Jawabannya adalah tidak. Dalam Marketing 4.0, digital marketing tidaklah menggantikan pemasaran tradisional. Sebaliknya, keduanya hadir bersama alias coexist di era sekarang. Keduanya saling mengisi peran satu sama lain, khususnya dalam perjalanan pelanggan atau customer path.

Asal tahu saja, di era konektivitas sekarang ini, customer path telah berubah. Dulu, dikenal dengan 4A, yakni Aware, Attitude, Act, dan Act Again. Sekarang, perjalanan pelanggan ini berubah menjadi 5A, yakni Aware, Appeal, Ask, Act, dan Advocate. Dalam customer path yang baru ini, pemasaran tradisional dan digital marketing bisa hadir secara bersama. Bisa jadi, misalnya, orang sadar akan sebuah produk melalui iklan tradisional di televisi. Lalu, kemudian ia bertanya secara online di media sosial, kemudian ia membeli, dan karena puas ia kemudian merekomendasikan produk tersebut ke komunitasnya, baik di media sosial maupun komunitas offline.

Akhirnya, pada intinya, Marketing 4.0 menjadi pendekatan pemasaran yang mengkombinasikan interaksi online dan offline yang tujuan utamanya adalah memenangkan advokasi konsumen.

Perbankan Syariah

Sekumpulan bank syariah yang berada di Indonesia saat ini terdiri dari Unit Usaha Syariah (UUS) dari bank konvensional yang membuka layanan syariah dan bank umum syariah (BUS) serta yang termasuk dalam rural bank yaitu bank pembiayaan rakyat syariah, dalam perhitungan asset yang diperhitungkan dalam Statistik Perbankan Syariah dalam diskusi ini adalah BUS dan UUS. Selama operasional bank syariah berdasarkan SPS bulan Oktober 2019 yang diterbitkan oleh Otoritas Jasa Keuangan (OJK) telah menghasilkan asset sebesar hamper 500 triliun dan seiring dengan perkembangan dari masa ke masa, permasalahannya di bank syariah adalah bagaimana meningkatkan market share bank syariah, setelah beroperasional dari tahun 1992 sampai saat ini baru mencapai market share sebesar 5.99 persen per Oktober 2019 dibandingkan bank konvensional yang 
telah beroperasi di Indonesia lebih dahulu mencapai asset sebesar 8.344 triliun per oktober 2019. Menurut Junaedi $(60,2015)$ perkembangan tujuh tahun terakhir asset bank syariah rata-rata dibawah satu persen, dengan demikian tidak mungkin asset bank syariah dalam sepuluh tahun kedepan akan menjadi diatas 15 persen. Dibutuhkan upaya luar biasa untuk meningkatkan marketshare bank syariah di era millennial industry 4.0 Pengembangan Hipotesis

Dalam diskusi ini dikembangkan dari formulasi pengaruh variable asset perbankan syariah terhadap market share bank syariah yang selama periode penelitian relative mengalami pertumbuhan secara kuantitatif dibawah satu persen, sementara perkembangan ilmu pemasaran dan teknologi digital telah merubah paradigma di pemasaran bukan hanya pada produk, lebih kepada memanusiakan manusia melalui piranti teknologi.

Variabel berikutnya adalah human capital, sumber daya insani yang mestinya factor penentu yang bisa meningkatkan value asset dan value bank syariah dalam era kompetitif dizaman milenial ini terhadap market share bank syariah dan variable yang menjadikan bank syariah lambat dalam pertumbuhan market share juga bisa menurunkan para pemimpin bank syariah, yaitu variable kredit macet terhadap market share bank syariah Indonesia.

\section{Riset Metodologi}

Diskusi metodologi menggunakan analisis regresi linear berganda, menurut Asra dkk $(30,2017)$ merupakan suatu teknik analisis statistic yang mempelajari hubungan antara sebuah variable terikat dengan beberapa variable bebas. Membicarakan tentang sampel penelitian, proses pengumpulan data dan tes validitas. Populasi dalam penelitian ini adalah industry perbankan syariah Indonesia yang terdiri dari Bank umum Syariah dan Unit usaha Syariah selama periode Oktober 2018 sampai dengan oktober 2019 dengan rincian sebagai berikut :

a. Bank Umum Syariah sebanyak 14 bank

b. Unit Usaha Syariah sebanyak 20 bank 


\section{Jurnal Asy-Syukriyyah}

\section{Pengumpulan data dan Tes Qualitas}

Sampel data yang digunakan adalah Statistik Perbankan Syariah periode Oktober 2019 yang diterbitkan secara regular oleh Otoritas Jasa Keuangan berupa data asset industry perbankan syariah, jumlah tenaga kerja di industry perbankan syariah dan non performing financing di Unit Usaha Syariah serta non performing financing di Bank Umum Syariah, data yang digunakan selama 13 bulan dari oktober 2018 sampai dengan oktober 2019.

Software yang digunakan untuk memproses pengolahan data menggunakan SPSS versi 22 uuntuk mengtahui validitas dan reliabilitas penelitian.

\section{Hipotesis}

Dalam penelitian ini menggunakan variable penelitian berupa asset bank syariah, tenaga kerja di bank syariah dan non performing financing bank syariah terhadap market share bank syariah, dengan hipotesis sebagai berikut :

H1 : Apakah asset bank syariah berpengaruh terhadap market share bank syariah

H2 : Apakah juumlah tenaga kerja di industry bank syariah berpengaruh terhadap market share bank syariah

H3 : Apakah non performing financing Unit usaha Syariah dan Bank Umum Syariah berpengaruh tehadap market share bank syariah

\section{Hasil Pengukuran}

Hasil pengukuran menggunakan software SPSS versi 22 menghasilkan output penelitian sebagaimana table sebagai berikut :

Tabel 1

Koefisien Determinan

Model Summary

\begin{tabular}{|l|r|r|r|r|}
\hline Model & $\mathrm{R}$ & \multicolumn{1}{|c|}{ R Square } & Adjusted R Square & Std. Error of the Estimate \\
\hline 1 & $.868^{\mathrm{a}}$ & .753 & .671 & .06891 \\
\hline
\end{tabular}

a. Predictors: (Constant), npf, asetbs, tks 


\section{Jurnal Asy-Syukriyyah}

Uji determinasi menunjukan bahwa nilai (Adjusted $\mathrm{R}$ Square) 0.67 hal ini menunjukan bahwa NPF, Tenaga kerja (human Capital) dan Aset Bank Syariah berpengaruh 67\% terhadap Marketshare (perbandingan asset bank syariah terhadap asset bank konvensional) dan sisanya 33\% dipengaruhi oleh variabel lain yang tidak diteliti.

Tabel 2

Anova

ANOVA $^{\mathrm{a}}$

\begin{tabular}{|ll|r|r|r|r|r|}
\hline Model & & Sum of Squares & df & Mean Square & F & Sig. \\
\hline 1 & Regression & .131 & 3 & .044 & 9.167 & $.004^{\mathrm{b}}$ \\
& Residual & .043 & 9 & .005 & & \\
& Total & .173 & 12 & & & \\
& & & & & \\
\hline
\end{tabular}

a. Dependent Variable: marketshare

b. Predictors: (Constant), npf, asetbs, tks

\section{Uji F-test}

Uji F digunakan untuk mengetahui apakah variabel-variabel independen secara simultan berpengaruh signifikan terhadap variabel dependen. Derajat kepercayaan yang digunakan adalah 0,05 . Apabila nilai $\mathrm{F}$ hasil perhitungan lebih besar daripada nilai $\mathrm{F}$ menurut tabel maka hipotesis alternatif, yang menyatakan bahwa semua variabel independen secara simultan berpengaruh signifikan terhadap variabel dependen. Outputnya sebagai berikut :

Tabel 2 menunjukan bahwa nilai $F_{\text {hitung }}$ sebesar 9.167 dengan tingkat (sig) 0.004 atau dapat nilai signifikansi 0.004 lebih kecil dari nilai probabilitas 0.005 .

"Hal tersebut membuktikan bahwa terdapat pengaruh signifikan antara Aset Bank Syariah, Tenaga kerja dan Non performing financing terhadap marketshare atau Secara Simultan (bersama-sama) Aset Bank Syariah, tenaga kerja dan NPF signifikan terhadap marketshare Bank Syariah” 
Tabel 3

Uji Parsial

Coefficients $^{\mathrm{a}}$

\begin{tabular}{|c|c|c|c|c|c|c|c|c|}
\hline \multirow{2}{*}{\multicolumn{2}{|c|}{ Model }} & \multicolumn{2}{|c|}{$\begin{array}{c}\text { Unstandardized } \\
\text { Coefficients }\end{array}$} & \multirow{2}{*}{$\begin{array}{c}\text { Standardized } \\
\text { Coefficients } \\
\text { Beta }\end{array}$} & \multirow[b]{2}{*}{$t$} & \multirow[b]{2}{*}{ Sig. } & \multicolumn{2}{|c|}{$\begin{array}{l}95.0 \% \text { Confidence Interval } \\
\text { for B }\end{array}$} \\
\hline & & B & Std. Error & & & & $\begin{array}{l}\text { Lower } \\
\text { Bound }\end{array}$ & $\begin{array}{l}\text { Upper } \\
\text { Bound }\end{array}$ \\
\hline & (Constant) & 5.282 & 1.498 & & 3.526 & .006 & 1.893 & 8.671 \\
\hline & asetbs & $6.081 \mathrm{E}-6$ & .000 & .683 & 3.943 & .003 & .000 & .000 \\
\hline & tks & $-2.909 E-5$ & .000 & -.262 & -1.510 & .165 & .000 & .000 \\
\hline & npf & -.120 & .060 & -.331 & -2.000 & .077 & -.256 & .016 \\
\hline
\end{tabular}

a. Dependent Variable: marketshare

\section{Uji $t$-test}

Uji t digunakan untuk mengetahui apakah variabel-variabel independen secara parsial berpengaruh nyata atau tidak terhadap variabel dependen. Derajat signifikansi yang digunakan adalah 0,05. Apabila nilai signifikan lebih kecil dari derajat kepercayaan maka kita menerima hipotesis alternatif, yang menyatakan bahwa suatu variabel independen secara parsial mempengaruhi variabel dependen. Outputnya sebagai berikut :

Uji statistik $t$-test (PARSIAL) menunjukan:

1. Pengaruh asset Bank Syariah ( $\varkappa 1)$ terhadap Marketshare Bank Syariah (Y) Aset Bank Syariah memiliki nilai signifikansi (Sig.) 0.003 pada tabel Coefficients ${ }^{\mathrm{a}}$ dengan nilai $\alpha$ (derajat signifkansi) 0.05 artinya $0.003<0.05$ atau Terdapat pengaruh yang signifikan asset Bank Syariah terhadap variabel terikat Marketshare Bank Syariah).

2. Pengaruh tenaga kerja $(\varkappa 2)$ dan NPF $(\varkappa 3)$ terhadap Markershare Bank Syariah (Y) Tenaga kerja dan NPF memiliki nilai signifkansi (Sig,) 0.167 dan 0,077 dengan nilai $\alpha$ (derajat signifkansi) 0.05 artinya 0.167 dan $0,077>0.05$ atau terdapat pengaruh yang tidak signifikan antara tenaga kerja dan NPF terhadap Marketshare Bank Syariah.

\section{Hasil dan Diskusi}

Memperhatikan data kinerja Bank Syariah selama 13 bulan terakhir menunjukan bahwa asset bank syariah tenaga kerja dan non performing financing secara bersama sama berpengaruh signifikan terhadap market share bank syariah, dengan hasil 67 persen, 33 


\section{Jurnal Asy-Syukriyyah}

persen dipengaruhi oleh variable lain yang tidak diteliti. Secara parsial variable asset bank syariah berpengaruh signifikan terhadap marketshare bank syariah dan variable tenaga kerja serta NPF tidak berpengaruh signifikan terhadap marketshare bank syariah.

Pertumbuhan asset bank syariah selama periode penelitian year on year bertumbuh sebesar 10,06 persen bersumber dari bank umum syariah sebesar 333,79 triliun dan unit usaha syariah sebesar 166,19 triliun.Kontribusi asset bank umum syariah bertumbuh sebesar 9,69 persen dan pertumbuhan aset unit usaha syariah sebesar 10.8 persen.

Tenaga kerja bank syariah tidak berpengaruh signifikan terhadap marketshare bank syariah, secara kuantitatif relative dalam masa penelitian tidak ada pertumbuhan positif justru selama periode penelitian mengalami pertumbuhan negative dan pada posisi Oktober 2019 kembali seperti pada posisi Oktober 2018 sebanyak 56.691 pekerja pada industry bank syariah, sehingga berdampak tidak signifikan terhadap marketshare bank syariah, sementara non performing financing juga sama seperti variable tenaga kerja, yaitu tidak signifikan berpengaruh terhadap marketshare bank syariah, selama periode penelitian NPF bank umum syariah mengalami pertumbuhan sebesar 0.46 persen bertumbuh positif dari 3,95 persen menurun menjadi 3,49 persen dan NPF unit usaha syariah selama periode penelitian mengalami pertumbuhan negative dari 2,32 persen pada posisi Oktober 2018 menjadi 2,57 persen pada posisi bulan Oktober 2019, meskipun posisi NPF unit usaha syariah lebih baik dari NPF bank umum syariah, yaitu 2,57 NPF UUS dan 3,49 NPF BUS. Apabila digabungkan posisi NPF UUS dan NPF BUS lebih buruk lagi yaitu sebesar 6,06 persen secara industry semestinya industry bank syariah harus dalam pengawasan khusus Otoritas Jasa Keuangan karena lebih dari yang disyaratkan yaitu maksimal NPF bank sebesar 5 persen, sehingga wajar kedua variable independen yaitu tenaga kerja dan non performing financing bank syariah tidak berpengaruh signifikan terhadap marketshare bank syariah.

Dekade 2020 bagi dunia perbankan syariah bukan hanya permasalahan pembiayaan macet saja yang harus diperbaiki, dizaman milenial industry 4.0 bila hanya focus pada pembiayaan macet tidak mungkin dapat tumbuh signifikan marketshare bank syariah, 


\section{Jurnal Asy-Syukriyyah}

disrupsi pada financial service jelas sebuah keadaan yang harus diantisipasi, karena bila tidak dilakukan integrasi antara penanganan internal industry menurunkan pembiayaan macet dengan marketing bank syariah, makin menyulitkan untuk meningkatkan pertumbuhan marketshare bank syariah, bila demikian quo vadis marketing perbankan syariah ? tidak focus pengembangan pada trend market milenial selama periode penelitian hanya tumbuh 0,48 persen. Oleh karena itu dibutuhkan strategi dan taktik untuk menumbuhkan marketshare yang lebih besar dengan makin peduli kepada manusia milenial melalui pemasaran bank syariah.

Finansial services yang mengalami disrupsi antara lain, branch office, card based payment, ATM, internet banking (web based), cash, customer service, traditional call center, sms banking, E money dan produk, bisnis serta industry yang mengalami pertumbuhan cryptocurreency, E commerce credit, Waqf, millennial friendly health insurance, online based application, pay later behavior, riba awareness, digital payment, online investment, financial planning, digital lending, game top up dan installment $0 \%$.

Untuk bisa hidup dialam milenial maka dibutuhkan strategi bisnis untuk bisa mengakomodir apa yang dibutuhkan oleh milenial, Yuswohadi dkk (2019) menyebutnya 7 Leap Strategies, yaitu :
a. Unlearn
b. Avoid FoD (Fear of Disruption)
c. Reframe the old mindset
d. Reskill for future digital competencies
e. Reinvent your industry
f. Think like a millennial
g. Leisurize your business

LEAP Strategy diawali dengan UNLEARN, yaitu menganggap diri kita "tak tahu semuanya”. Survive dari disrupsi itu bukanlah semata masalah teknologi digital atau inovasi model bisnis. Yang terpenting justru adalah masalah mindset Yaitu mindset yang menganggap bahwa kita telah "tahu semuanya" Ketika kita sudah merasa tahu semuanya 


\section{Jurnal Asy-Syukriyyah}

maka semakin sulit pula kita menanggalkannya. Itu sebabnya disruptor di industri otomotif bukanlah Toyota yang "tahu semuanya" tentang otomotif, tapi oleh Tesla dan Google. Disruptor perhotelan bukan Hilton tapi Airbnb yang"tak tahu semuanya". Disruptor layanan taksi bukanlah Blue Bird tapi Uber. Mindset "tahu semuanya" telah membutakan mata, hati, dan pikiran kita mengenai hal baru yang tidak kita ketahui. Di tengah disrupsi, mindset yang diperlukan bukanlah "tahu semuanya", tapi justru sebaliknya "tak tahu semuanya". Kita tak cukup sebatas LEARNING tapi juga UNLEARNING yaitu mengosongkan hal-hal usang yang selama berpuluh tahun kita ketahui dan kita yakini kebenarannya. Unlearning akan mengosongkan isi pikiran kita sebersih mungkin sebersih kanvas kosong.

Saat ini kata DISRUPTION telah menjadi momok menakutkan bagi pelaku bisnis. Ketika pebisnis diliputi ketakutan, maka keputusan yang mereka ambil cenderung blunder. Mereka cenderung mengambil jalan teraman dengan terus WAIT \& SEE... Tak melakukan apa-apa. Di tengah ketakutan mereka cenderung:

a. Melihat gelas "setengah kosong", bukan "setengah penuh".

b. Menyikapi disruption sebagai THREAT, bukan OPPORTUNITY.

c. Meresponnya secara REAKTIF, bukan PROAKTIF.

Ketakutan di tengah disrupsi menciptakan ENDOWMENT EFFECT, yaitu tendensi dimana orang secara irrational menilai terlalu tinggi apa-apa yang telah dimiliki, karena itu mati-matian ia tak akan melepaskannya (LOSS AVERSION).

Para inkumben tak rela jika perusahaannya "digembosi" oleh startup digital milik kids jaman now. Loss aversion yang berlebihan ini menjadikan mereka semakin kalut, kalap, dan tidak tahu bagaimana cara menghadapi dan mengelola disrupsi, maka hindari :
a. FEAR of DISRUPTION
b. PANIC-driven EXECUTIONS
c. LEAD by IGNORANCE

Di tengah disrupsi, model bisnis lama dalam posisi UNDER ATTACK oleh startup digital. Setiap pemain harus siap melakukan BUSINESS MODEL INNOVATION 
agar relevan di NEW NORMAL. Kunci melakukan inovasi model bisnis adalah REFRAMING, yaitu“membalik mindset” bagaimana kita mencipta nilai (value creation), dari logika industri lama ke logika yang baru.Contohnya, perusahaan taksi tradisional dibangun dengan mindset lama bahwa OWNERSHIP of assets (kendaraan dan pengemudi) adalah faktor kunci memenangkan persaingan. Namun startup digital seperti GoJek atau Grab menggunakan mindset baru bahwa ACCESS lebih penting dari ownership. REFRAMING dari ownership ke access adalah dasar kita melakukan inovasi model bisnis yang menjamin relvansi kita di lanskap industri yang baru (new normal). Follow these FOUR steps:

\#1. Identify the CORE BELIEFS of the existing industry

\#2. Map the SUPPORTING BELIEFS the dominant business model

\#3. Think the OPPOSITE

\section{\#4. Invent the REFRAMED BELIEFS}

REVOLUSI INDUSTRI 4.0 mulai menemukan CRITICAL SCALE. 2020 adalah juga tahun RESKILLING karyawan dimana kompetensi harus memadukan kemampuan HUMAN+ROBOT. Seperti saat peralihan dari Revolusi Industri 1.0 ke 2.0 dimana pekerjaan pertanian bergeser ke manufaktur; memasuki Revolusi 4.0 pekerjaan akan bergeser dan didominasi oleh digitisasi, otomasi, AI, data analytics, dll. Kompetensi karyawan harus diperbarui secara radikal. RESKILL or DIE

\section{\#1. Key Partner: Fulfilment -> COCREATION}

Partner kini berperan tak hanya menjadi enabler pemenuhan kebutuhan konsumen, tapi secara strategis melakukan kokreasi untuk memberikan solusi terbaik ke konsumen.

\section{\#2. Key Activity: Efficiency -> INTELLIGENCE}

Google dan Tesla tidak mengejar efisiensi, tapi intelijen. Semakin banyak kita menggunakan mesin pencari Google, makin ia akan semakin pintar. Begitu pula semakin banyak kita menggunakan mobil Tesla, maka mobil itu akan semakin cerdas. Welcome to the era of artificial intelligence. 


\section{Jurnal Asy-Syukriyyah}

\section{\#3. Key Resource: Ownership -> ACCESS}

Logika lama mengatakan, untuk memenangkan persaingan perusahaan harus menguasai dan memiliki aset dan sumber daya. Namun aset jika tidak dikelola mumpuni justru menjadi beban overhead yang berat. Bisnis zaman now justru menggunakan prinsip assetlight dimana akses lebih penting dari kepemilikan aset.

\section{\#4. Value Proposition: Product -> PLATFORM}

Android tidak menawarkan produk tapi platform yang memungkinkan pihak lain yaitu para pengembang aplikasi berkreasi mengembangkan beragam varian produk yang memenuhi kebutuhuhan unik/customized dari setiap pengguna smartphone.

\section{\#5. Customer Relationship: Loyalty -> EMPOWERMENT}

Era customer loyalty telah lewat. Cara terbaik untuk mempertahankan konsumen kini justru dengan membebaskan dan membuat mereka berdaya (empowered). Google AdSense misalnya, membuat para pemilik blog berdaya dalam mendatangkan trafik. Ini good untuk mereka, dan tentu good untuk Google.

\section{\#6. Channel: Intermediary -> ECOSYSTEM}

GoJek menjangkau konsumennya dengan pendekatan ekosistem. Itu sebabnya GoJek begitu agile bergerak dari layanan transportasi penumpang ke pengiriman barang, pengiriman makanan, layanan pijat, penjualan tiket, hingga system pembayaran.

\section{\#7. Customer Segment: Customer -> PROSUMER}

Wikipedia tidak menulis sendiri jutaan konten bermutu yang disajikan ke kita. Wikipedia menyerahkan penulisan itu kepada kita semua. Artinya, kita tidak hanya menjadi konsumen Wikipedia, tapi sekaligus juga produsen. Istilah kerennya: Prosumer.

\section{\#8. Cost Structure: Low Cost -> ZERO}

Model bisnis free tercipta karena teknologi digital memungkinkan beberapa konsumen mengonsumsi produk digital secara bersamaan dengan marginal cost yang mendekati nol. Belajar online (MOOC: Massive Open Online Course) misalnya, bisa dilakukan bersamaan oleh jutaan mahasiswa tanpa ada tambahan biaya berarti. 


\section{Jurnal Asy-Syukriyyah}

\section{\#9. Revenue Stream: Direct -> INDIRECT}

Google, Facebook, atau Twitter menggratiskan layanannya ke konsumen. Kita tak perlu membayar untuk memakai Google Search, Gmail, atau Google Map. Lalu dari mana Google dapat duit? Dari pengiklan (indirect).

Berpikir seperti milenial, apapun produk dan bisnisnya kita harus menggunakan perspektif berpikir milenial, produk dan bisnis harus milenial friendly, karakteristik milenial friendly, antara lain :

a. More for less, milenial meminta banyak dengan biaya serendah mungkin

b. Peers, milenial membutuhkan kunci dalam membentuk preferensi, sikap dan pengambilan keputusan pembelian

c. Share, bagi milenial acces lebih penting dari ownership, mereka penggerak sharing economy

d. Esteem, milenial adalah instagram generation yang mencari aktualisasi, pengakuan dan eksistensi diri

e. Speed simplicity convenience, kecepatan, kesimpelan dan bebas repot adalah kemutlakan bagi milenial

f. Happiness, milenial adalah happiness seeker dan experience seeker, karena itu fun, mindfulness dan wellbeing penting bagi milenial

Leisurize our business, diera leisure revolution kota tidak cukup menawarkan utilitas produk, tapi harus menciptakan experience plus connection kepada milenial. Apapun produk dan bisnis kita haru sdapat menciptakan memorable moment, moment of significant, moment of recognition, moment of expression, moment of creativity, moment of happiness dll.

\section{KESIMPULAN}

Dalam penelitian ini variabel independen adalah asset bank syariah, tenaga kerja dan non performing financing dan variable dependen adalah marketshare bank syariah, sampel penelitian menggunakan data dari statistic perbankan syariah Indonesia selama 


\section{Jurnal Asy-Syukriyyah}

periode Oktober 2018 sampai dengan Oktober 2019, dengan pengolahan data menggunakan software SPSS versi 22 dan hasil penelitian menunjukan bahwa dengan uji F diketahui hasilnya seluruh variable independen secara simultan berpengaruh terhadap varvariablependen yaitu marketshare bank syariah dengan nilai signifikan 0.004 dengan nilai signnifikansi sebesar 67 persen dan 33 persen dipengaruhi variable lain yang tidak diteliti, hasil uji T menunjukan bahwa secara parsial variable independen yang signifikan adalah variable asset bank syariah terhadap marketshare bank syariah sebesar 0,003 dan variable tenaga kerja serta variable non performing financing tidak berpengaruh secara signifikan dengan nilai diatas 0.05 persen yaitu 0,167 dan 0,077 .

Secara kuantitatif asset bank syariah berpengaruh signifikan selama periode penelitian mengalami pertumbuhan diatas 10 persen, sementara variable tenaga kerja tidak signifikan selama periode penelitian relative tidak mengalami pertumbuhan positif dan variable non performing financing dalam periode penelitian mengalami pertumbuhan makin besar nilai non performing financing bank umum syariah sebesar 3,49 persen dan non performing financing unit usaha syariah sebesar 2,57 persen. Marketshare bank syariah selama periode penelitian hanya tumbuh sebesar 0,48 persen kurang dari 1 persen.

Quo vadis marketing bank syariah di era milenial industry 4.0, dibutuhkan strategi dan taktik untuk meningkatkan marketshare bank syariah dengan 7 Leap Strategies, yaitu unlearn, Avoid fear of disruption, reframe the old mindset, reskill for future digital competencies, reinvent industry, think like a millennial dan leisurize your business. 


\section{Jurnal Asy-Syukriyyah}

\section{DAFTAR PUSTAKA}

Asra, Abuzar dkk; Analisis multivariable suatu pengantar, Penerbit In media; Tahun 2017

Junaedi, Edy; Qou vadis Market Share Bank Syariah Indonesia, Jurnal Asy-syukriyyah volume 15 Edisi Desember 2015.

Kartajaya, Hermawan \& Mussry, Jacky; Entrepreural Marketing Compass \& Canvas, Penerbit PT. Gramedia Pustaka Utama; Tahun 2017

Kotler, Philip dkk; From product to Customer to The human Spirit Marketing 3.0; Penerbit John Wiley \& Son, Tahun 2010.

Schneider, Stefan; Current Issues Clobal Growth centres, Deutsche Bank Research; August 1, 2005

Statistik Perbankan Indonesia volume 17 no.11, periode bulan oktober 2019, Otoritas Jasa Keuangan; tahun 2019

Statistik Perbankan Syariah periode Oktober 2019, Otoritas Jasa Keuangan; tahun 2019

Yuswohadi dkk, Marketing Outlook 2020, The Fall and The Rise it's Time to Leap, Strategy in time Market Inflection; Inventure, 2019. 